\title{
PARTICIPÁCIA TALIANSKYCH HISTORIKOV Z KONCA 19. STOROČIA NA ŠÍRENÍ CYRILO-METODSKÉHO KULTU (PIETRO BALAN, PIETRO PRESSUTTI, GAETANO ALIMONDA, DOMENICO BARTOLINI) ${ }^{1}$
}

\author{
The Participation of Italian Historians From the End of the 19th Century \\ in Spreading the Cyrillo-Methodian Cult \\ (Pietro Balan, Pietro Pressutti, Gaetano Alimonda, Domenico Bartolini)
}

\author{
Martina Lukáčová
}

DOI: $10.17846 /$ CL.2020.13.1.177-186

\begin{abstract}
LUKÁČOVÁ, Martina. The Participation of Italian Historians From the End of the 19th Century in Spreading the Cyrillo-Methodian Cult (Pietro Balan, Pietro Pressutti, Gaetano Alimonda, Domenico Bartolini). The author mainly dedicated her study to the Cyrillo-Methodian cult and put emphasis on the way of its representation in the works of that period of time whose common feature is a specific historical period - the end of the 19th century Apart from this, focuses her attention on the common geographical provenience of the authors of the introduced works that is Italy. In the text, the author aim at some works of Pietro Balan, Pietro Pressutti, Gaetano Alimonda and Domenico Bartolini, which she selected on the basis of two temporal and conceptual criteria in the course of the papacy of Leo XIII: the year 1880 - the release of the Encyclical Grande munus - and the year 1881 the organisation of ta thanksgiving pilgrimage in Rome in the presence of the Slavs. Not less essential point of our research is the specification of the existence of the Cyrillo-Methodian cult in the discussed works using analytical and comparative methods. In our contribution, we finally try to synthesise the gained results in the form of defining of common traits in understanding and the way of representation of the Cyrillo-Methodian tradition in the analysed works of the above stated Italian historians.
\end{abstract}

Keywords: the Cyrillo-Methodian cult, pope Leo XIII, Encyclical Grande munus, Pietro Balan, Pietro Pressutti, Gaetano Alimonda, Domenico Bartolini

Abstrakt: LUKÁČOVÁ, Martina. Participácia talianskych historikov z konca 19. storočia na širení cyrilo-metodského kultu. Pietro Balan, Pietro Pressutti, Gaetano Alimonda, Domenico Bartolini. V štúdii sa prioritne venujeme cyrilo-metodskému kultu s dôrazom na spôsob jeho stvárnenia $\mathrm{v}$ dobových dielach, ktorých spoločným menovatelom je vyšpecifikované historické obdobie - koniec 19. storočia. Okrem toho našu pozornost’ sústredujeme na spoločnú geografickú provenienciu autorov uvádzaných diel, ktorou je Taliansko. V texte sme sa zamerali na niektoré diela Pietra Balana, Pietra Pressuttiho, Gaetana Alimondu a Domenica Bartoliniho, ktoré sme vyselektovali na báze dvoch časových a ideových kritérií $\mathrm{v}$ priebehu pontifikátu Leva XIII.: rok 1880 - zverejnenie encykliky Grande munus a rok 1881 - zor-

Táto práca bola podporovaná Agentúrou na podporu výskumu a vývoja na základe Zmluvy č. APVV-160116 a vznikla tiež v rámci projektu KEGA č. 004UKF-4/2018 Európsky stredovek interaktívne. 
ganizovanie dakovnej púte $\mathrm{v}$ Ríme za účasti Slovanov. Nemenej podstatným bodom nášho výskumu je konkretizácia existencie kultu sv. Cyrila a Metoda v pertraktovaných dielach s využitím analytických a komparatívnych metód. Napokon sa v štúdii pokúsime o syntetizáciu nadobudnutých výsledkov formou definovania spoločných čŕt v chápaní a spôsobe zobrazovania cyrilo-metodskej tradície $\mathrm{v}$ analyzovaných dielach vyššie uvedených talianskych historikov.

Klúčové slová: cyrilo-metodský kult, pápež Lev XIII., encyklika Grande munus, Pietro Balan, Pietro Pressutti, Gaetano Alimonda, Domenico Bartolini

\section{Úvod}

Osobnost’ a dielo pápeža Leva XIII. (1810 - 1903; pontifikát v období rokov: 1878 - 1903) podstatne súvisí s cirkevnými dejinami Slovanov. Doposial existujúce výskumy zaoberajúce sa vztahmi Svätej stolice k slovanskej otázke (v širšom ponímaní k východným cirkvám) na úrovni historicko-politickej či diplomatickej dokladujú významné intervencie zo strany Leva XIII. z obdobia druhej polovice 19. storočia. ${ }^{2} \mathrm{~V}$ týchto súvislostiach nebolo možné zo strany historikov (v prevahe cirkevných) opomenút existenciu a význam pápežovej encykliky Grande munus z roku $1880^{3}$, ktorá predstavovala jeho jednoznačnú politickú i morálnu oporu a priazeň v riešení slovanskej otázky. V pozadí týchto aktivít pontifika je všadeprítomný cyrilo-metodský kult, ktorý slúži ako puto zbližujúce slovanské národy so Svätou stolicou. Reakciou na idey prezentované v encyklike bola priama odpoved' - účast' Slovanov na púti zorganizovanej v Ríme v dňoch 25. júna - 5. júla 1881, ktorú pútnici zavŕšili pápežskou audienciou. ${ }^{4}$

V súlade so zámerom predkladanej štúdie pozornost̉ sústred’ujeme na talianskych historikov z konca 19. storočia, ktorí sa prítomnosti cyrilo-metodského kultu (vo vyššie spomínanom kontexte) vo svojich historických dielach venovali. Detailnejšie sa formou analýzy zameriame na výstupy Pietra Balana (1840 - 1893), Pietra Pressuttiho (? - ?), Gaetana Alimondu (1818 - 1891), ako aj Domenica Bartoliniho (1813 - 1887). Motiváciou nášho výberu práve spomínaných historikov bolo skúmanie dobových materiálov z uvedeného obdobia, ktoré odzrkadlujú vtedajšiu autentickú atmosféru, resp. reagujú na udalosti, ktoré sa v tom čase odohrávali. Stredobodom nášho záujmu je charakter prítomných informácií o existencii, diele, ako aj hodnotách, ktoré sv. Cyril a Metod prinášajú. V neposlednom rade nás zaujíma zdrojový materiál, z ktorého v kontexte cyrilo-metodskej problematiky historici čerpali.

Spomedzi mnohopočetných diel renomovaného talianskeho cirkevného historika Pietra Balana $^{5}$ sme vybrali publikáciu Il Pontificato di Giovanni VIII (Pontifikát Jána VIII.) ${ }^{6}$. Ide o trojzväzkové dielo z roku 1880, t. j. ešte pred zorganizovaním rímskej púte s účastou zástupcov zo slovanských radov v roku 1881. Vzhladom na bezprostrednú súvislost' v skúmaní cyrilo-metodskej

2 O pontifikáte Leva XIII. a jeho encyklike Grande munus (1880) pozri bližšie: Hromják 2010; Hromják 2011a, 199-222; Hromják 2011b, 13-28; Hromják 2013, 545-562; Lopatková 2013, 247-249; Tolomeo 2015, 203-222; Ambros 2018, 57-59;

3 Pápež v nej okrem iného stanovil, aby sa všeobecne platným dňom slávenia úcty sv. Cyrilovi a Metodovi stal 5. júl, čím dochádza ku kodifikácii cyrilo-metodského kultu v katolíckej cirkvi.

4 O danej púti pozri bližšie: Slotta 1882; Koželuha 2004, 59-99; Lopatková 2013, 249-250; Lopatková 2014, 69-77; Ivanič 2018, 69; Ivanič 2019, 98-106.

5 Podrobné biografické údaje o Pietrovi Balanovi možno dohladat na: http://www.treccani.it/enciclopedia/ pietro-balan_\%28Dizionario-Biografico\%29/.

6 Vzhladom na to, že originálne texty $\mathrm{v}$ taliančine, s ktorými pracujeme, nie sú oficiálne preložené do slovenčiny, uvádzame ich vlastné preklady. 
problematiky a dejín starých Slovanov treba upozornit na tretiu podkapitolu Gli slavi (Slovania), no predovšetkým na nasledujúcu štvrtú podkapitolu I moravi (Moravania); Giovanni VIII e la chiesa di Pannonia (Moravania; Ján VIII. a Panónska diecéza), kde sa Balan (1880a, 9-10) zmieňuje o solúnskych vierozvestcoch výlučne v historickom kontexte na základe udalostí spojených $s$ definovaním pôsobenia Slovanov. Na stránkach tohto diela podáva charakteristiku tohto etnika, venuje sa konkrétne jeho výzoru, popisu správania či miestu výskytu. Sv. Cyrila a Metoda spomína v súvislostiach ich vstupu na územie Vel'kej Moravy formou zhrňujúcich informácií o ich tamojších aktivitách: „Okolo roku 863 dvaja apoštoli Chazarov a Bulharov, Cyril a Metod, vstúpili na Moravu, ktorá okolo roku 867 sčasti konvertovala na krestanstvo. Cyril (tu) našiel starobylé slovanské písmo, ktoré obohatil a uviedol medzi tento národ a v tom istom jazyku tu rozšíril liturgiu. Po týchto činoch sa Cyril opät' utiahol do kláštora; zostal iba Metod, ktorého v roku 868 povolal do Ríma pápež Hadrián II. a vysvätil ho za biskupa a vyhlásil ho za metropolitu Panónie a Moravy a preložil Bibliu do slovanského jazyka. "Dôležitost tejto publikácie spočíva predovšetkým v dokladovaní informácií o slovanskej mnohovekej a prevratnej histórii vrátane prítomnosti sv. Cyrila a Metoda na tomto území, ako aj o dovtedy neznámom registri pápeža Jána VIII. v súvislosti so schvalovaním slovanskej liturgie vo vztahu k rakúskym a mad’arským historikom, pre ktorých boli tieto názory v tom čase neakceptovatelné (Hromják 2013, 560). Balan (1880a, 10) sa odvoláva okrem iného na zdrojový materiál od pol'ského historika Jana Długosza $(1415-1480)^{7}$ a českého filológa a historika Josefa Dobrovského $(1753-1829)^{8}$, z ktorého čerpal faktografické údaje, no upozorňuje i na svoje ovela detailnejšie rozpracovanú esej vzhladom na túto problematiku pod názvom La Chiesa cattolica e gli Slavi (Katolícka Cirkev a Slovania) ${ }^{9}$, ktorá bola uverejnená v tom istom roku. Sám historik v predhovore definuje túto publikáciu ako historickú esej, ktorá v sebe nenesie apologické ani polemické prvky. Za dôležité pri jej koncipovaní považuje Balan $(1880 \mathrm{~b}, 7)$ využívanie pravdivých faktov o cirkevných a civilných dejinách Slovanov, ktoré nadobudol okrem iného intenzívnym a minucióznym výskumom originálnych dokumentov nachádzajúcich sa vo vatikánskych archívoch ${ }^{10}$. Pripomína, že ide aj o doposial’ nevydané pramene, ku ktorým sa bežný čitatel’ s najväčšou pravdepodobnostou nie je schopný dostat. Ďalej sa odvoláva na encyklopedické osemzväzkové dielo Illyricum sacrum $(1751$ - 1819) z pera talianskeho historika Danieleho Farlatiho (1690 1773), ktorého erudovanost' v oblasti dejín Slovanov Balan (1880b, 6-7) mimoriadne vyzdvihuje. V rozpätí rokov 1751 - 1775 napísal prvých pät zväzkov vyššie spomínanej publikácie a neskôr ho nahradil jeho pokračovatel, historik a polyglot Giacomo Coleti (1734 - 1827). Popri týchto historikoch skúmajúcich slovanské dejiny akcentoval tiež osobný prínos v podobe využitých zdrojov františkánskeho teológa a historika Luka (Lukasa) Waddinga (1588 - 1657), prefekta Tajného vatikánskeho archívu (1855 - 1870), kanonika a nemeckého cirkevného historika Augustina Theinera (1804 - 1874) či uhorského historika, profesora histórie a knihovníka Juraja (Györgyho) Praya (1723 - 1801). Pertraktovanú Balanovu historickú esej možno chápat ako priamu reakciu na encykliku Grande munus $(1880)^{11}$, dokonca vyznieva v jeho podaní ako ústredný motivický prvok

Annales seu cronicae incliti Regni Poloniae.

8 Cyrill und Method der Slawen Apostel: ein historisch-kritischer Versuch (1823).

9 Dielo sa uvádza aj pod nasledovnými názvami: Le relazioni fra la Chiesa e gli Slavi (Vztahy medzi Cirkvou a Slovanmi); Delle relazioni fra la Chiesa cattolica e gli Slavi della Bulgaria, Bosnia, Serbia, Erzegovina (O vztahoch medzi katolíckou Cirkvou a bulharskými, bosnianskymi, srbskými a hercegovinskými Slovanmi) - toto rozšírené pomenovanie sa nachádza na prvom liste eseje.

10 Vzhladom na to, že Balan pracoval ako archivár (II. stupňa - uvedené na titulnom liste, ako aj v predhovore knihy) v Tajnom vatikánskom archíve (dnes Apoštolskom vatikánskom archíve), konzultoval pri svojom výskume originálne diela zozbierané v edícii regestov Regesti Ponteficii, čo pokladal za unikátnu možnost garantujúcu autenticitu, hodnovernost' a z nich prameniacu objektívnost' predkladaných faktov.

11 Encyklika bola zverejnená 30. septembra 1880. 
diela. Explicitne vyjadruje svoje sympatie voči pápežovi Levovi XIII. a jeho počinom v súvislosti s doterajšími vztahmi Západu voči slovanskému etniku. Samozrejme, vtedajšieho pápeža nepovažuje svojimi činmi za ojedinelého, i ked’ výnimočného, z jeho vyjadrení je evidentné, že háji vo všeobecnosti pápežské snahy (pontifikát Mikuláša I. (858 - 867), Hadriána II. (867 - 872) či Jána VIII. $\left(872-882^{12}\right)$ ) v dejinách Svätej stolice ohladom uznania existencie slovanských národov a ich dôležitosti i vel'kosti v rámci historiografie katolíckej cirkvi. Úsilie Leva XIII. šírit cyrilo-metodský kult predstavuje zavŕšenie snáh jeho predchodcov. Práve svojimi aktivitami si sv. Cyril a Metod vyslúžili označenie apoštolov a „ochrancov viery na celom krestanskom Východe. “(Balan $1880 \mathrm{~b}, 10)$. Tematicky sa v eseji tento taliansky historik zvlášt koncentroval na zber a interpretáciu dobových údajov o bulharských, bosnianskych, srbských a hercegovinských Slovanoch, kedže túto čast̉ slovanských dejín považuje na jednej strane v Taliansku za menej prebádanú na rozdiel od území Uhorska, Dalmácie, Moravy, ako aj Čiech, ktoré disponujú renomovanými historikmi referujúcimi o prelomových historických udalostiach vzbudzujúcich ich záujem, na strane druhej vidí motiváciu práve $\mathrm{v}$ tristnej a nejasnej d’alekosiahlej existenčnej situácii týchto etnických spoločenstiev nielen v minulosti, ale aj v budúcnosti. Cyrilo-metodský kult v Balanovej publikácii chápeme ako isté ideové spojivo, ktoré Svätej stolici jeho propagáciou poslúžilo k vytváraniu dôležitého recipročného ${ }^{13}$ vztahu medzi Západom a Východom v šírení katolíckej viery. Okrem toho výrazne podporuje uvedomenie si zdroja hodnôt, ktorý sú Slovania schopní priniest'. V prípade, že našu pozornosṫ chceme orientovat výlučne na zastúpenie cyrilo-metodskej tradície v tejto publikácii, je potrebné akcentovat tretiu kapitolu mapujúcu prítomnost' a aktivity solúnskych bratov (v kapitole pod názvom: Sv. Cyril a sv. Metod na Morave a v Ríme; smrt’ sv. Cyrila; a v dalších podkapitolách: Ortodoxnost' sv. Cyrila; Spory voči sv. Metodovi; Obhajoba sv. Metoda zo strany Jána VIII.; Sv. Metod v Ríme; ortodoxnoste jeho doktríny, schválenie Jána VIII; Jeho smrṫ. V kapitolách IV. - XVII. detailne analyzuje v chronologickom slede historické skutočnosti odohrávajúce sa na území južných Slovanov. Posledná, osemnásta kapitola obsahuje zhrňujúce informácie o vztahoch, ktoré panovali medzi pápežmi a Slovanmi v minulosti, ako aj so súdobým pápežom Levom XIII., ktorému sa Balan venuje v samostatnej podkapitole.

Podobne tematicky a ideovo ladené dielo vytvoril v tom istom roku historik Pietro Pressutti pod názvom Il papato e la civiltà degli slavi meridionali (Pápežstvo a civilizácia južných Slovanov). Ide o prejav, ktorý autor predniesol 18. marca 1880 v Akadémii katolíckej cirkvi (Accademia di religione cattolica, 1801) ${ }^{14}$, t. j. niekol'ko mesiacov pred zverejnením encykliky Grande munus a dokončením Balanovho textu La Chiesa cattolica e gli Slavi (Katolícka Cirkev a Slovania), ktorý je datovaný 5 . decembra 1880 . Z uvedeného je zrejmé, že tento rímsky historik z tohto zdroja nečerpal, no nachádzame tu odvolávku na d’alšie jeho omnoho skôr vydané monotematické dielo o pápežovi Jánovi VIII. ${ }^{15}$ (Pressutti 1880, 26). Istým spoločným menovatelom pri identifikácii zdrojovej bibliografie pri koncipovaní uvedených diel je citovanie, resp. parafrázovanie identických historiografických diel Farlatiho či Theinera ${ }^{16}$. Nemenej významné sú pre historika bibliografické

12 Pontifikátu Jána VIII. sa Balan podrobne venuje v samostatnom diele, o ktorom sme sa už v texte zmienili.

13 Máme na mysli fakty z dejín Slovanov, ktoré by mohli byt prospešné pre Talianov (západné civilizácie vo všeobecnosti), ako aj naopak rímske dejiny pre celé slovanské etnikum.

14 Známa aj pod názvom Pontificia Accademia della Religione Cattolica - neskôr Università Gregoriana (Pápežská univerzita Gregoriana): jej zakladatelom bol v roku 1801 Giovanni Zamboni (1756 - 1850); konali sa tu raz mesačne zhromaždenia, kde boli prezentované diskusie z oblasti teológie, filozofie a histórie, ich výstupy boli publikované.

15 Balan, Pietro. 1876. Storia di Giovanni VIII. Modena. 187-189.

16 Vicende della Chiesa Cattolica in Russia e in Polonia (1843); Vetera monumenta Slavorum meridionalium historiam illustrantia (1863); Vetera monumenta Hungariae (1859 - 1860). Pressutti $(1880,73-83)$ 
zdroje od Josepha Augustina Ginzela ${ }^{17}$ (1804 - 1876), Antonína Bočka $\left(1802\right.$ - 1847) ${ }^{18}$ i Louisa Légera $(1843-1923)^{19}$, ktoré nachádzame v citačných odkazoch tejto publikácie. Z formálneho hladiska možno poukázat na analyzované Pressuttiho dielo predovšetkým použitím lahko rozpoznatelných rečníckych jazykových prostriedkov, charakteristických pre tento štylisticky vyhranený typ textu. Hoci dielo obsahuje množstvo dôležitých historiografických dát, vyniká schopnostou autora prízvukovat prediskutovávanú tému s odvolávaním sa na predispozície adresáta. Považuje za nutné už v úvode svojej rozpravy pomerne precízne vysvetlit pojem civilizácia, ktorý kladie do roviny filozoficko-historickej a predstavuje pre neho ústredný motivický bod, od ktorého sa rozprava odvíja. V tejto súvislosti od všeobecného pojmu prechádza plynule k slovanskej rodovej línii, neskôr až k južným Slovanom, ktorí predstavujú dominantný objekt Pressuttiho záujmu. Rozmach dejín a civilizácie, ako aj celkový vzostup Slovanov je podla Pressuttiho $(1880,7)$ dielom krestanstva, ktoré od čias pápeža Jána IV. (pontifikát v trvaní rokov: 640 - 642) preniklo najskôr na územie Chorvátska a Srbska a neskôr v 8. storočí do Korutánska a do Štajerska, následne medzi Moravanov, kde príchodom solúnskych bratov a založením sídla ich apoštolátu dochádza k vyvrcholeniu kristianizačných snáh na tomto území s ich nedozernými hodnotami pre celé slovanské etnikum v minulosti, ako aj v súčasnosti. Práve toto teritórium sa stalo centrom krestanstva a kultivovanosti, odkial' vyšli nové impulzy rozptylujúce sa medzi ostatných južných Slovanov (Pressutti $1880,8)$. Medzi obsahom a formou panuje v analyzovanom diele silná korelácia, čím sa autorovi podarilo textom zapôsobit na recipienta či už v podobe pléna, alebo čitatela. Z hladiska definovania foriem stvárnenia, resp. prítomnosti cyrilo-metodského kultu je potrebné dat dôraz na oblast’ jazyka a literatúry, ktorými sa v nemalej miere Pressutti (1880, 19-22) zaoberá. Vyzdvihuje zlomový a d’alekosiahly podiel $\mathrm{v}$ tejto rovine, o ktorý sa svojou činorodostou zaslúžili sv. Cyril a Metod. Začiatky kultúry Slovanov pramenia $\mathrm{v}$ „katolicizme, a ich jazyk a literatúra, základy rozvoja civilizácie, sa rodia a formujú v katolíckych kostoloch pod záśtitou a ochranou pontifikátu. [...] Pôvod slovanského jazyka a literatúry bol za posledných pätdesiat rokov témou živých diskusií najerudovanejších slavistických filológov a literátov. Problém spočíva v troch otázkach [...] “, ktoré historik vidí v konkretizácii diel sv. Cyrila a Metoda z hladiska ich proveniencie, dalej v definovaní konkrétneho slovanského jazyka, v ktorom obidvaja písali a napokon v určení, či autorstvo cyriliky a hlaholiky možno prisúdit sv. Cyrilovi (Pressutti 1880, 19). V rámci tejto nastolenej problematiky spomína už existujúce práce Šafárika (1761 - 1831), Dobrovského (1753 - 1829), Kopitara (1780 - 1844), Palackého (1798 - 1876), Lelewela (1786 - 1861), Jagića (1838 - 1923), Hattalu (1821 - 1903), Miklošiča (1813 - 1891) a i. Konštatuje, že hoci otázka písma ešte nie je úplne doriešená, je nesporné literárne diela vierozvestcov definovat’ s využitím výhradne v liturgii a sú jasným zavŕšením ich apoštolátu. Neopomína tiež podčiarknut význam a hodnoty slovanského jazyka, ktorý sa stáva vyjadrovacím prostriedkom aj v iných celospoločenských oblastiach (vedy a literatúry), pre ludstvo vtedajšej, ako aj budúcej doby.

$\mathrm{V}$ tejto štúdii sme doteraz analyzovali diela talianskych historikov, ktoré boli vytvorené v roku 1880 ako priama reakcia na idey prezentované pápežom v encyklike Grande munus. Ďalším objektom nášho záujmu sú historické diela skoncipované v nasledujúcom roku 1881, t. j. v období, ked’ sa konala d’akovná pút slovanských národov v Ríme.

sa v prílohe súbornej publikácie Theinerovým zdrojovým dokumentom venuje podrobne s odvolávkou na ich bližšie rozpracovanie v rokoch 1863 a 1875.

17 Geschichte der Slawenapostel Cyrill und Method und der slawischen Liturgie (1861).

18 Codex diplomaticus et epistolaris Moraviae (1836 - 1903): Pressutti $(1880,10)$ čerpal z listín, ktoré boli publikované v roku 1839.

19 Cyrille et Méthode étude historique sur la conversion des slaves au christianisme (1868). 
Práve rozpravu L’apostolato slavo dei Santi Cirillo e Metodio in ordine alla religione, alla letteratura e alla politica (Slovanský apoštolát svätých Cyrila a Metoda vo vztahu k náboženstvu, literatúre a politike $)^{20}$ od Pietra Pressuttiho možno zasadit do tejto skupiny. Ide o historikove myšlienky a názory, ktoré sprostredkoval v Akadémii katolíckej cirkvi (Accademia di religione cattolica) 2. júla 1881 pri príležitosti tejto púte. $V$ úvodnej časti publikácie okrem explicitných pochvalných vyjadrení plných úcty a pokory na adresu sv. bratov Cyrila a Metoda a ich vel'kolepého apoštolského diela, pomenúva súvislosti, ktoré nachádza medzi nimi, slovanským etnikom a Svätou stolicou. Velmi jasne odhaluje smer, ktorým sa chce v tomto diele uberat', resp. z ktorých konkrétnych aspektov bude na aktivity a ich konzekvencie solúnskych vierozvestcov nazerat. Text diskusie týkajúcej sa cyrilo-metodského kultu orientuje okolo dvoch bodov, najskôr sa vyjadruje k výhodám, ktoré ludstvo môže $\mathrm{z}$ ich apoštolátu vytažit vo vztahu k náboženstvu, literatúre a politike v súvislostiach s rímskym pontifikátom a následne prechádza k historickému náhladu na túto problematiku, ked’uvádza niekol'ko nepodložených názorov, na ktoré upozorňuje, no za istú bernú mincu v jeho skúmaní treba pokladat predovšetkým zdokumentované údaje, cez prizmu ktorých na dejiny hladí (Pressutti, 1881, 4-5). Bibliografické zdroje, z ktorých čerpal sa vo väčšej miere zhodujú s už uvedenými v jeho diele z roku 1880. Ďalej vyzdvihuje prínos kardinála Domenica Bartoliniho (1813 - 1887), ktorého publikáciu budeme analyzovat samostatne. Okrem materiálu zameraného na rozbor dejinných udalostí, zoznamuje čitatela s informáciami prameniacimi v spisbe nasledujúcich encyklopedistov, filológov či filozofov: Johanna Gottfrieda Grubera (1774 - 1851), Johanna Samuela Erscha (1766 - 1828), Gottfrieda Wilhelma Leibniza (1646 - 1716), Luigiho Taparelliho d’Azeglia (1793 - 1862), ktorými sa nechal inšpirovat'. Pressutti je verný chronológii, ktorú naznačil v úvode publikácie a postupne prechádza od popisu Slovanov a ich mytológie, biografických údajov o solúnskych bratoch, ich misií, k náboženským otázkam ako primárnej zložke skutočnej civilizácie (podrobnejšie rozoberá úlohu apoštolátu sv. Cyrila a Metoda na slovanskom území a porovnáva ho s pôsobením apoštolov na iných európskych územiach), v tejto súvislosti vyzdvihuje ich počiny späté so vznikom a etablovaním písma, ktoré nadobúda platnost' v literatúre (dôkladne uvažuje nad polemikou týkajúcou sa pôvodu i autorstva hlaholiky a cyriliky; ako aj nad podrobnou charakteristikou jazyka, v ktorom sv. Cyril a Metod na slovanskom území komunikovali a napísali svoje diela, t. j. rozhodujúcou otázkou pre dejiny slovanskej filológie). Doposial pertraktované náboženstvo a kultúra vrátane jazyka a literatúry sú nespornými benefitmi, ktoré vierozvestcovia Slovanom sprostredkovali, no Pressutti $(1881,21-45)$ navádza recipienta k zamysleniu sa nad dalším ich prínosom, a to vo vztahu k politike (na popisnej historickej báze analyzuje vzájomné vztahy medzi jednotlivými panovníkmi (predovšetkým vel'komoravskými a východofranskými), ako aj ich väčšie či menšie väzby na pontifikát).

Dňa 6. júla 1881 za účasti pápeža Leva XIII. predniesol vo Vatikáne kardinál Gaetano Alimonda svoj inauguračný prejav pod názvom Agli Slavi pellegrini in Roma (Slovanským pútnikom v Ríme). $\mathrm{V}$ istej časti textu sa priamo a osobitne obracia na predstavitelov jednotlivých slovanských národov, ktorých na začiatku oslovuje a adresuje im čast’ výkladu, v ktorom využíva a vyzdvihuje špecifiká charakteristické pre daný slovanský región v podobe jeho osobností či geografického definovania (Alimonda 1881, 16-18). Na stránkach tejto rozsahom nevel'kej publikácie sa o chvályhodných činoch sv. Cyrila a Metoda pre napredovanie slovanského etnika autor vyslovuje so značnou úctou a rešpektom. Možno povedat', že hoci týmto myšlienkam nevenuje žiadnu ucelenú čast’ textu, idey

20 Obidve vyššie analyzované Pressuttiho rozpravy boli publikované v súbornom diele v roku 1881 v Ríme pod názvom La Santa Sede e gli slavi (Svätá stolica a Slovania), ktoré jeho autor venoval Josipovi Jurajovi Strossmayerovi (1815 - 1905). Naším zdrojovým materiálom, ktorý uvádzame v bibliografickom zozname, boli samostatne dohladané, resp. vydané rozpravy. Kedže sme mali možnost̉ analyzovat aj súborné dielo, pri porovnávaní textov v tomto diele, ako aj v samostatnej verzii sme postrehli, že nie sú úplne identické a v istých pasážach sa sčasti formálne (štylisticky) líšia, i ked’ obsahový kontext je zachovaný. 
obsahujúce cyrilo-metodskú tradíciu sa tiahnu komplexne celým dielom. Z hladiska formálnej stránky nesie v sebe Alimondov text jasné znaky rečníckeho prejavu, a teda nemožno očakávat takú obrovskú kumuláciu zdrojového materiálu, ako sa to udialo v niektorých predtým analyzovaných historických dielach. Aj napriek tomuto tvrdeniu nemožno opomenút práce od historikov, ktorých sme už v tejto štúdii spomenuli, ako napr. Pietra Balana či Augustina Theinera, z ktorých Alimonda evidentne čerpal a uviedol ich vo svojom poznámkovom aparáte.

Posledné dielo, ktoré sme sa rozhodli analyzovat, je rozsiahla publikácia z roku $1881 \mathrm{~s}$ názvom Memorie storico-critiche archeologiche dei Santi Cirillo e Metodio (Historicko-kritické archeologické spomienky sv. Cyrila a Metoda ${ }^{21}$ z pera kardinála a prefekta Kongregácie pre rítus Domenica Bartoliniho. Dielo je prioritne venované slovanským pútnikom, ktorí v letných mesiacoch roku $1881 \mathrm{v}$ čase d’akovnej púte zavítali do Ríma. Bartolini hned'v úvode podáva vysvetlenie, prečo sa rozhodol koncipovat text o slovanskom etniku, resp. o existencii cyrilo-metodského kultu. Domnievame sa, že vtedy prebiehajúce udalosti vo Vatikáne pod patronátom pápeža Leva XIII. boli tou najvhodnejšou príležitostou k prezentovaniu historikových ideí. Jeho klúčovým zámerom bolo dovtedy známe historicko-geografické bibliografické zdroje k dejinám slovanského etnika, ako aj informácie o živote a diele sv. Cyrila a Metoda hlbšie preskúmat a sprístupnit širšiemu spektru príjemcov. Podla neho je tento úsek dejín stále nedostatočne prebádaný a vzhladom na velkost tohto etnika nedocenený. Jeho počiatky nutne spája so solúnskymi bratmi. Pozornost̉ venuje predovšetkým zdrojom - legendám, ktoré sa viažu na ich apoštoláty u jednotlivých slovanských národov, autor ich uvádza pod nasledujúcimi názvami: Leggenda Italica (Romana); Leggenda Sanctorum Cyrilli et Methodii Patronorum Moraviae (Moravica); Boemica; Pannonica. ${ }^{22}$ Podrobne vysvetluje genézu ich vzniku a obsahovú stránku. Okrem toho jeho pozornosti v súvislosti s popisovaním dobových prameňov neunikli ani pápežské listy či malby v Bazilike sv. Klementa v Ríme. Ďalej sa s rešpektom a chválou vyjadruje o diele Pietra Balana Delle relazioni fra la Chiesa cattolica e gli Slavi della Bulgaria, Bosnia, Serbia, Erzegovina (O vztahoch medzi katolíckou Cirkvou a bulharskými, bosnianskymi, srbskými a hercegovinskými Slovanmi) z roku 1880, ako aj o obidvoch vyššie analyzovaných Pressuttiho publikáciách z roku 1880 a 1881, priamo sa tiež odvoláva na už spomínaného Ginzela, Palackého, Šafárika či Bočka (Bartolini 1881, VI-XXIX). Text Bartolini rozdelil na štyri obsiahle kapitoly, ktoré v časovej línii na základe biografických údajov osvetlujú nielen jednotlivé etapy zo života a smrti sv. Cyrila a Metoda, ale aj prínos ich vel'kolepého diela.

\section{Záver}

Cielom našej štúdie bolo upriamit’ pozornost’ na vybrané práce talianskych historikov (Pietra Balana, Pietra Pressuttiho, Gaetana Alimondu, Domenica Bartoliniho) z konca 19. storočia, ktorí istú čast' svojej tvorby venovali rozvoju cyrilo-metodskej tradície. Postupnou analýzou spomínaných diel sme sa snažili o pochopenie ich motivácie pri výbere tejto tematiky, o popisovanie obsahovej stránky diel a v neposlednom rade nás zaujal zdrojový materiál, z ktorého historici čerpali. Možno konštatovat, že fakty, ktoré všetci autori popisujú vo svojej spisbe pochádzajú prakticky z rovnakých dobových prameňov, na čo v texte upozorňujeme. $Z$ dôvodu lepšej logickej i formálnej prehladnosti podávame štruktúrované informácie o spisbe týchto historikov s ohladom na existenciu dvoch ústredných motivických bodov - historických udalostí (vznik encykliky Grande munus (1880) a pút Slovanov do Ríma v roku 1881 za účelom vyjadrenia vd’aky pápežovi

${ }_{21}$ Kompletné znenie názvu diela: Memorie storico-critiche archeologiche dei Santi Cirillo e Metodio e del loro apostolato fra le genti slave.

22 K podrobnejšej charakteristike týchto legiend pozri bližšie: MMFH II. 2010. 
Levovi XIII.), ktoré sme na tento ciel' využili. V samotnom texte sa teda postupne venujeme najskôr dielam, ktoré boli publikované v roku 1880 a potom pristupujeme k analýze diel z roku 1881 . Vo všetkých analyzovaných publikáciách predstavuje cyrilo-metodský kult významný podklad pre definovanie dejín Slovanov a je v nich vo väčšej či menšej miere obsiahnutý. Pertraktované udalosti nutne spájané s pôsobením pápeža Leva XIII. prispeli významným podielom k rozširovaniu cyrilo-metodskej tradície v povedomí odbornej, ako aj laickej verejnosti. Za ich dôsledok, resp. akési logické vyústenie možno pokladat práve vybrané analyzované diela spomínaných talianskych cirkevných historikov v tejto štúdii. Sú dôkazom ich neochvejnej túžby pozdvihnút znalosti o velkosti i schopnosti slovanského etnika a recipročného vztahu medzi ním a katolíckou cirkvou cez prizmu existencie a aktivít solúnskych vierozvestcov.

\section{REFERENCES}

Alimonda, Gaetano. 1881. Agli Slavi pellegrini in Roma. Roma.

Ambros, Pavel. 2018. Encyklika Lva XIII. Grande munus (1880), apoštolský list sv. Jana Pavla II. Egregiae virtutis (1980) a jejich vlyv na proměnu témat a funkcí cyrilometodějské tradice ve 20. a 21. století. In Ivanič, Peter (ed.). Cyrilometodějská tradice v novodobých československých dějinách. Zlín, 55-63.

Balan, Pietro. 1880a. Il Pontificato di Giovanni VIII. Roma.

Balan, Pietro. 1880b. La Chiesa cattolica e gli Slavi. Roma.

Bartolini, Domenico. 1881. Memorie storico-critiche archeologiche dei Santi Cirillo e Metodio. Roma.

Hromják, L’uboslav. 2010. Lo slavismo cattolico di Leone XIII e gli Slovacchi. Praha.

Hromják, Luboslav. 2011a. Lev XIII. a jeho doba. In Duchovný pastier 92/5, 199-222.

Hromják, Luboslav. 2011b. Leone XIII, il movimento slavo e le origini di Bohemicum. In Parma, Tomáš (ed.). Dal Bohemicum al Nepomuceno. Roma - Olomouc, 13-28.

Hromják, Luboslav. 2013. Cyrilo-metodský kult a jeho miesto v katolíckom slavizme Leva XIII. In

Bánik, Tomáš et al. Tradícia a prítomnost' misijného diela sv. Cyrila a Metoda. Nitra, 545-562.

Ivanič, Peter. 2018. Cyrilo-metodská úcta na Slovensku v 19. a 20. storočí. In Ivanič, Peter (ed.).

Cyrilometodějská tradice v novodobých československých dějinách. Zlín, 65-81.

Ivanič, Peter. 2019. Encyklika Grande munus a jej odozva u slovenských katolíkov. [The Encyclical Grande Munus and a Response to It from the Slovak Catholics]. In Konštantínove listy [Constantine's Letters] 12/2, 98-106.

Koželuha, František. 2004. Poư Slovanů do Ř́ma ke dni našich apoštolů sv. Cyrila a Metoděje r. 1881. In Laurenčík, Jiří (ed.). Paměti o věcech náboženských. II. svazek. Prostějov, 59-177.

Lopatková, Zuzana. 2013. Cyrilo-metodská tradícia na stránkach Katolíckych novín (1870 1904). In Bánik, Tomáš et al. Tradícia a prítomnost' misijného diela sv. Cyrila a Metoda. Nitra, 244-255.

Lopatková, Zuzana. 2014. Cyrilo-metodská tradícia a trnavské centrum posledných bernolákovcov (do konca 19. storočia). In Ideové prvky národného príbehu v dlhom 19. storočí. Bratislava, 69-77.

MMFH II. 2010. Bartoňková, Dagmar - Večerka, Radoslav (eds.). Magnae Moraviae Fontes Historici II. Praha.

Pressutti, Pietro. 1880. Il papato e la civiltà degli slavi meridionali. Roma.

Pressutti, Pietro. 1881. Lapostolato slavo dei Santi Cirillo e Metodio in ordine alla religione, alla letteratura e alla politica. Roma. 
PARTICIPÁCIA TALIANSKYCH HISTORIKOV Z KONCA 19. STOROČIA NA ŠíRENí CYRILO-METODSKÉHO KULTU (Pietro Balan, Pietro Pressutti, Gaetano Alimonda, Domenico Bartolini)

Slotta, Juraj. 1882. Pamiatka putovania katolíckeho Slavianstva do Rímu k hrobu sv. Cyrilla apoštola slavianskeho a ku slávnosti, kterú Jeho Svätost’ Pápež - Král Lev XIII. ku cti svätých Cyrila a Methoda na deň 3., 4. a 5. júlia 1881 v bazilike sv. Klementa zriadit’ a vykonat ráćil. Praha.

Tolomeo, Rita 2015. La visione slava di Leone XIII e il culto cirillo-metodiano. In I Santi Cirillo e Metodio e la loro eredità religiosa e culturale, ponte tra Oriente e Occidente. Cittá del Vaticano, 203-222.

http://www.treccani.it/enciclopedia/pietro-balan_\%28Dizionario-Biografico\%29/.

SUMMARY: THE PARTICIPATION OF ITALIAN HISTORIANS FROM THE END OF THE 19TH CENTURY IN SPREADING THE CYRILLO-METHODIAN CULT (PIETRO BALAN, PIETRO PRESSUTTI, GAETANO ALIMONDA, DOMENICO BARTOLINI). The aim of the referred contribution was to bring attention to the selected works of Italian historians (Pietro Balan, Pietro Pressutti, Gaetano Alimonda, Domenico Bartolini) from the end of the 19th century who a certain part of their writings dedicated to the development of The Cyrillo-Methodian tradition. By a gradual analysis of the mentioned works, the author tried to conceive their motivation choosing this topic, description of the content of the works and last but not least she was engaged with the source material, which the historians utilised. It is possible to assert that the facts which all authors describe in their writing, derive from practically the same source which we point to in the text. By reason of better logical and also formal transparency, the author gives a structured information about the writing of these historians with regard to the existence of two central motivic points - historical events (the release of the Encyclical Grande munus (1880) and the pilgrimage of the Slavs in 1881 for the purpose of expressing their gratitude to pope Leo XIII which she uses for this aim. First of all, author gradually deals with the works in the text itself, which were published in 1880 , and then, she approaches the analysis of the works from 1881. Chronologically, the author firstly assesses respected historian Pietro Balan $(1840$ - 1893) and his publications Il Pontificato di Giovanni VIII (The Papacy of John VIII) and La Chiesa cattolica e gli Slavi (The Catholic Church and the Slavs), then, she continues in the analysis with Pietro Pressutti (? - ?) by whom she also selected two works - speeches Il papato e la civiltà degli slavi meridionali (The Papacy and Civilisation of the Southern Slavs) and Lapostolato slavo dei Santi Cirillo e Metodio in ordine alla religione, alla letteratura e alla politica (The Slavic Apostolate of St Cyril and Methodius in Relation to the Religion, Literature and Politics), it follows the inauguration speech Agli Slavi pellegrini in Roma (To Slavic Pilgrims in Rome) from cardinal Gaetano Alimonda (1818 - 1891) and finally, there is a relatively voluminous publication by Domenico Bartolini (1813 - 1887) with the title Memorie storico-critiche archeologiche dei Santi Cirillo e Metodio (Historical-Critical Archaeological Memoirs of St Cyril and Methodius).

In all analysed publications, the Cyrillo-Methodian cult presents the important background for defining the history of the Slavs and it is involved to a greater or lesser degree in them. The discussed events necessarily connected with the activity of pope Leo XIII significantly contributed to spreading of the Cyrillo-Methodian tradition in the awareness of the laic and professional public. It is possible to consider the selected analysed works of the mentioned Italian church historians in this contribution their consequence, or, more precisely, a logical result. They are the evidence of an unwavering desire to enhance the knowledge about the greatness and also the ability of the Slavic ethnicity and a reciprocal relationship between him and the Catholic Church through the prism of the existence and the activities of Sts Cyril and Methodius, the missionaries of Thessalonica. 
MARTINA LUKÁČOvá

Mgr. Martina Lukáčová, PhD.

Constantine the Philosopher University in Nitra

Faculty of Arts

Department of Romance Studies

Hodžova 1

94974 Nitra

Slovakia

mlukacova@ukf.sk 